\title{
Article \\ Evaluation of the Risk Induced by Soil Erosion on Land Use. Case Study: Guruslău Depression
}

\author{
Andreea Costea ${ }^{1, *}$, Stefan Bilasco ${ }^{1,2, * \mathbb{D}}$, Ioan-Aurel Irimus ${ }^{1}$, Sanda Rosca ${ }^{1}$ D , Iuliu Vescan ${ }^{1}$, Ioan Fodorean ${ }^{1}$ (D) \\ and Paul Sestras ${ }^{3}$ (D) \\ 1 Faculty of Geography, Babes-Bolyai University, 400006 Cluj-Napoca, Romania; \\ aurel.irimus@ubbcluj.ro (I.-A.I.); sanda.rosca@ubbcluj.ro (S.R.); iuliu.vescan@ubbcluj.ro (I.V.); \\ ioan.fodorean@ubbcluj.ro (I.F.) \\ 2 Cluj-Napoca Subsidiary Geography Section, Romanian Academy, 400015 Cluj-Napoca, Romania \\ 3 Faculty of Civil Engineering, Technical University of Cluj-Napoca, 400020 Cluj-Napoca, Romania; \\ psestras@mail.utcluj.ro \\ * Correspondence: andreea.costea@ubbcluj.ro (A.C.); stefan.bilasco@ubbcluj.ro (S.B.)
}

Citation: Costea, A.; Bilasco, S.; Irimus, I.-A.; Rosca, S.; Vescan, I.; Fodorean, I.; Sestras, P. Evaluation of the Risk Induced by Soil Erosion on Land Use. Case Study: Guruslău Depression. Sustainability 2022, 14, 652. https://doi.org/10.3390/ su14020652

Academic Editor: Daniela Smiraglia

Received: 19 November 2021

Accepted: 30 December 2021

Published: 7 January 2022

Publisher's Note: MDPI stays neutral with regard to jurisdictional claims in published maps and institutional affiliations.

Copyright: (C) 2022 by the authors. Licensee MDPI, Basel, Switzerland. This article is an open access article distributed under the terms and conditions of the Creative Commons Attribution (CC BY) license (https:// creativecommons.org/licenses/by/ $4.0 /)$.

\begin{abstract}
Changes in land use, increasing of agricultural areas to the detriment of wooded ones, and poor management of agricultural land, along with the impact of current changes in the climate (reflected in the increase of the climate aggression index) makes soil erosion one of the main risks associated with improper land use, with a direct impact on its productivity and an indirect impact on human beings. The aim of this study is to assess the risk induced by surface soil erosion on land use, using as our main method of investigation the development of two models of integrated spatial analysis of the territory: a derived model of the universal soil loss equation (USLE) and a qualitative model that integrates the result of soil erosion assessment with the database representing the land use. This was carried out in order to highlight the impact on the territory. The spatial analysis models were developed on a structure of vector spatial databases, through which the soil type, soil texture, climate aggression coefficient, and land use were mapped, and alphanumeric databases, representing the market cost of land, in EUROs, that highlight the quality of cultivated land (in terms of productive economic potential). The induced risk estimation is based on a qualitative rating of soil erosion vulnerability on a scale from 1 to 5 (1-low vulnerability; 5-high vulnerability) and of the reduction of the economic value of the land (according to the vulnerability rating). The implemented methodology highlights the quantitative risk, with a maximum value of about 46.000 EUROs, spatially identified on large surfaces on the outskirts of the Jibou municipality. It is mainly caused by the impact of soil erosion on large areas of orchards, which provide necessary products for human consumption. The present methodology can be implemented on similar areas and can be used as a model of good practices in risk assessment based on financial losses by local public authorities.
\end{abstract}

Keywords: soil erosion; USLE; land degradation; risk evaluation

\section{Introduction}

Soil erosion represents one of the main factors causing land degradation [1,2]. It affects agricultural land $[1,3,4]$, forestland $[2,5,6]$, and pastures $[1,5,7]$. The productivity of the agricultural land is reduced by soil erosion [3] due to the removal of the fertile topsoil part [8,9], and may cause risk processes such as creeping or mudflow [10]. Besides, soil erosion affects forest ecosystems, causing the reduction of plant species and, as a whole, impacting the stability of the entire ecosystem [6]. The stability and biodiversity of the pastures are also reduced due to soil erosion [7], increasing its susceptibility to drought [1]. Among soil erosion types (wind erosion, water erosion, rainfall erosion, glacial erosion etc.), erosion induced by rainfall is the most significant [11-14] and is the main cause of land degradation worldwide, influencing about $56 \%$ of the total surface affected by soil degradation [15], or about 11 million $\mathrm{km}^{2}$ worldwide [9]. This form of 
soil erosion is widespread regardless of climatic conditions, so this occurs in almost all countries [12], but its incidence is higher in countries with humid, tropical and subtropical climate, characterized by heavy rainfall, since the intensity of rains has a more significant impact on runoff and, as a consequence, accelerates the soil erosion [16].

The environment and economy are two important domains where the soil erosion has a pronounced impact $[17,18]$, which manifests itself through some mechanisms; soil quality is degraded [19], the productivity of agricultural land decreases [1], and the agricultural production costs are higher [20]. Soil erosion removes fertile topsoil from agricultural land [21] and transports it to waterbodies [19]. This process has a manifold effect: on the one hand, the cultivated surfaces are reduced, causing the deduction of agricultural production [19] which may threaten food security. On the other hand, soil erosion may produce the degradation of water resources, causing even the eutrophication of waterbodies [1]. Moreover, soil erosion may lead to the siltation of waterbodies [22], which requires additional financial costs in order to preserve water resources [23].

Soil erosion is closely related to climate changes that the planet has been facing in recent years $[5,24,25]$, and it has increased due to these changes [26,27]. The main process through which climate influences soil erosion rate is the intensification of the erosive capacity of precipitation [24,27], due to the increasing of its quantity and intensity [28-30].

The increase in temperature on a global scale, along with the greenhouse effect, leads to a more vigorous hydrological cycle [14,26,31]. This mechanism causes changes in the precipitation regime, materialized by frequent episodes of heavy rainfall [32] with high kinetic energy that accelerates soil erosion $[18,19]$ and removes in this way particles from surface topsoil [33]. Climate changes also influence soil erosion by increasing the level of soil moisture [30], that has the effect of increased runoff and reduced water infiltration rates $[16,26,32]$.

Soil erosion has become one of the most significant geographical hazards in the world [3,11,33-35], and is among the main causes of land degradation [19]. In addition to this, soil erosion has economic, social, and environmental implications and is considered a threat to food security [36]. The economic effects of soil erosion are significant [33,36] and are materialized by increasing production costs on medium and long term, due to the necessity of using fertilizers and due to lower crop productivity [20,37].

The effects of soil erosion can be grouped into two major categories: on-site and offsite [27,38-40]. Among the on-site effects there are loss of effective rooting depth, depletion of plant nutrients, decline in soil structure, and reduction in soil quality [27]. The off-site effects are materialized by possible floods, sedimentation, and pollution $[27,33,36]$.

Soil erosion is assessed through several empirical models [18,28,41,42]. Among these, the USLE (universal soil loss equation) is an efficient tool used on a global scale [10,14,19, $43,44]$ in order to estimate soil loss due to soil erosion [45]. The USLE model was improved and computerized, creating a tool with a predictive role, called RUSLE (revised universal soil loss equation) [46]. The RUSLE is based on the integrated analyses of the climatic factor, soil, topography and land use, to estimate its impact on soil erosion [19]. The impact of soil is analyzed by soil structure, texture, permeability, and organic matter content [47].

The USLE was implemented to assess soil erosion in regions with tropical and subtropical climate $[4,18,47,48]$, regions with Mediterranean climate $[3,43,49,50]$, in North America [26,41], and in Europe [51,52]. The main areas analyzed were those depending on agriculture $[5,13,19]$, as this is the domain where soil erosion has direct effects on the population, with implications regarding agricultural production and food security [10,19].

The USLE was implemented to assess risk of soil erosion on agriculture where it may have an impact on food resources, highlighting the fact that there is a risk of their significant decrease due to low land productivity (which may even cause famine) $[18,19,27,47,48]$. The soil erosion risk on water resources was also assessed $[41,43]$ in order to estimate the probability that they would become unusable in the long term and to estimate the costs of their maintenance $[19,23]$. In addition, the USLE was used to evaluate risks in the field of engineering for the implementation of soil erosion control strategies [53], as 
well as in the economic and environmental fields, to develop proper land management strategies $[1,33,36,38]$. Moreover, the USLE was used to analyze the spatial distribution of soil erosion prone areas $[10,49]$ and to make predictions regarding the evolution of soil erosion [4] and the changes it may cause on the land use [25,30]. The purpose of the USLE model was to assess the risk induced by soil erosion in different domains [27] in order to establish measures of control and mitigation [19], to make predictions on medium and long-term evolution of soil erosion [10,18], and also to adapt the soil conservation strategies $[43,54]$.

The geomorphological processes with the major impact in the recent period within the Guruslău Depression are soil erosion and landslides. These are the main risk factors, as well as elements of restriction in terms of land use. The effects of these processes are more significant in the field of agriculture, on which the population is financially dependent, and on the spatial development of the area. The USLE model is an efficient tool through which the amplitude of soil erosion in the study area can be quantified, integrating both criteria related to the natural and human components.

The present study aims to assess the areas affected by soil erosion and soil loss, and also to make predictions regarding the evolution of this process, in the Guruslău Depression. This approach is useful in order to develop an efficient land management plan, to identify the proper land management practices to reduce soil erosion, and to reduce its negative impact.

\section{Study Area}

The Guruslău Depression is located in a regional context approximatively in the center of the North-West Development Region of Romania, at the border of Sălaj and Maramures, counties, so that its area of influence can be extended to the whole region (Figure 1). It is also located along the Somes, River, one of the main rivers in the region, which has multiple implications: on the one hand, its terraces are fertile and suitable for agriculture and, on the other hand the study area is transited by the connecting axis related to Somes, Valley, materialized by the railway, the $\mathrm{DN} 1 \mathrm{H}$ national road and the county road that connects the two counties, thus favoring the flows of people, mass and energy.

The study area occupies about 14,000 hectares and includes large areas within the communes of Benesat, Năpradea, and Someș-Odorhei, but also a large part of one of the four urban centers in the county (the city of Jibou). It is important that over $50 \%$ of the territory of Guruslău Depression is occupied by agricultural land, which gives it a significant agricultural specificity, that individualizes it in relation to neighboring areas, where the population works in domains as tourism, industry or resource exploitation. This also has direct implications for the employment structure of the population, as most of the inhabitants work in the primary sector. For example, in the village of Năpradea there are crops of flax, hemp and vines, as well as dairy products; in the village of Somes-Odorhei vegetable growing is intensely practiced; in Benesat and Someș-Guruslău, cattle breeding predominates. The city of Jibou is served both by the peripheral agricultural area, which is the main supplier of agri-food products, and by the rest of the settlements in the area. Meanwhile, the Guruslău Depression is located in the proximity of two major urban centers in the county, Zalău and Cehu Silvaniei, which are markets for the agricultural products obtained in the territory and could absorb a large part of the agricultural production from the study area (if it would be directed to them).

According to previous studies on climate change, in the last 30 years there has been an increase in the intensity and frequency of extreme climatic episodes [55,56], all of which have a direct impact on soil erosion and surface runoff [57]. The increase in precipitation intensity influences the surface runoff and implicitly the soil erosion [58-60]. An increase in heavy rainfall in areas where agricultural land management is deficient also causes degradation of agricultural plots and meadows [61], thus influencing environmental factors, inducing the need for the analysis performed in the present study. 


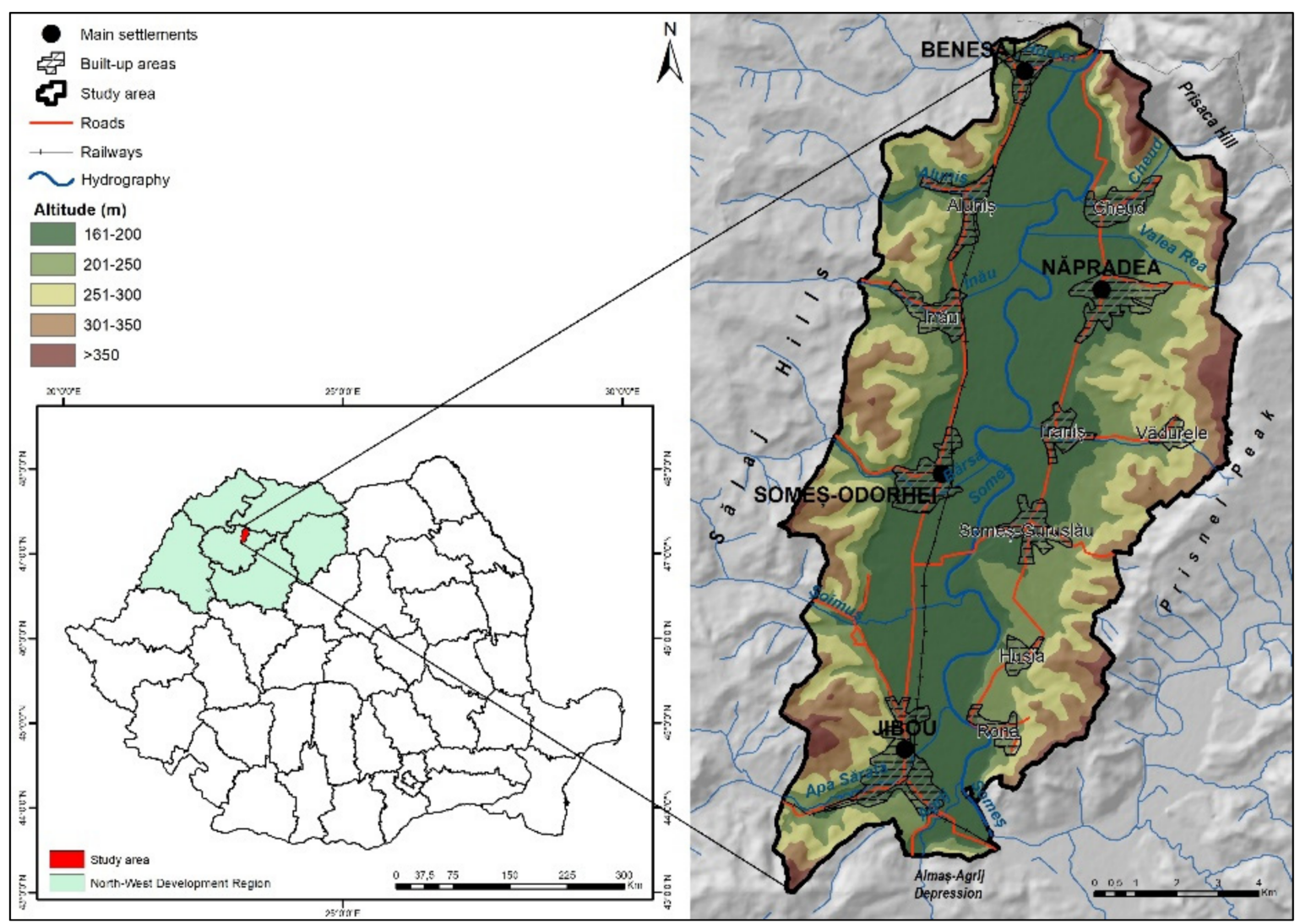

Figure 1. Geographical position of the study area.

The identification of the areas vulnerable to soil erosion in the Guruslău Depression and the establishment of measures to combat and prevent this process may have the effect of increasing agricultural productivity. In this way, the area may become a major supplier of agricultural products in the region, expanding its polarization area in neighboring counties due to its midway position in relation to the large consuming centers, such as Baia Mare, Satu Mare, Dej, and Cluj-Napoca. Besides, the agricultural products can be sold outside the area by increasing the number of collection and processing centers of these products, as nowadays there is only one such center in the village of Năpradea. The effects of this would be the economic development of the area and the increase of the living standard of the population.

\section{Materials and Methods}

The evaluation of the soil erosion rate was performed based on the implementation of the USLE model in the GIS software, in the form of a spatial analysis model, developed to estimate annual soil losses, with the main purpose of assessing the risks caused by soil erosion. The model is an efficient tool used to coordinate the efficient management of the soil erosion susceptible areas since it has a predictive role regarding the evolution of affected areas in the medium and long term. The USLE model is particularly suitable for the assessment of soil erosion in the field of agriculture, where the analysis of soil erodibility and the quantification of soil losses are mainly targeted, with the aim of assessing land in terms of agricultural productivity (Figure 2). 


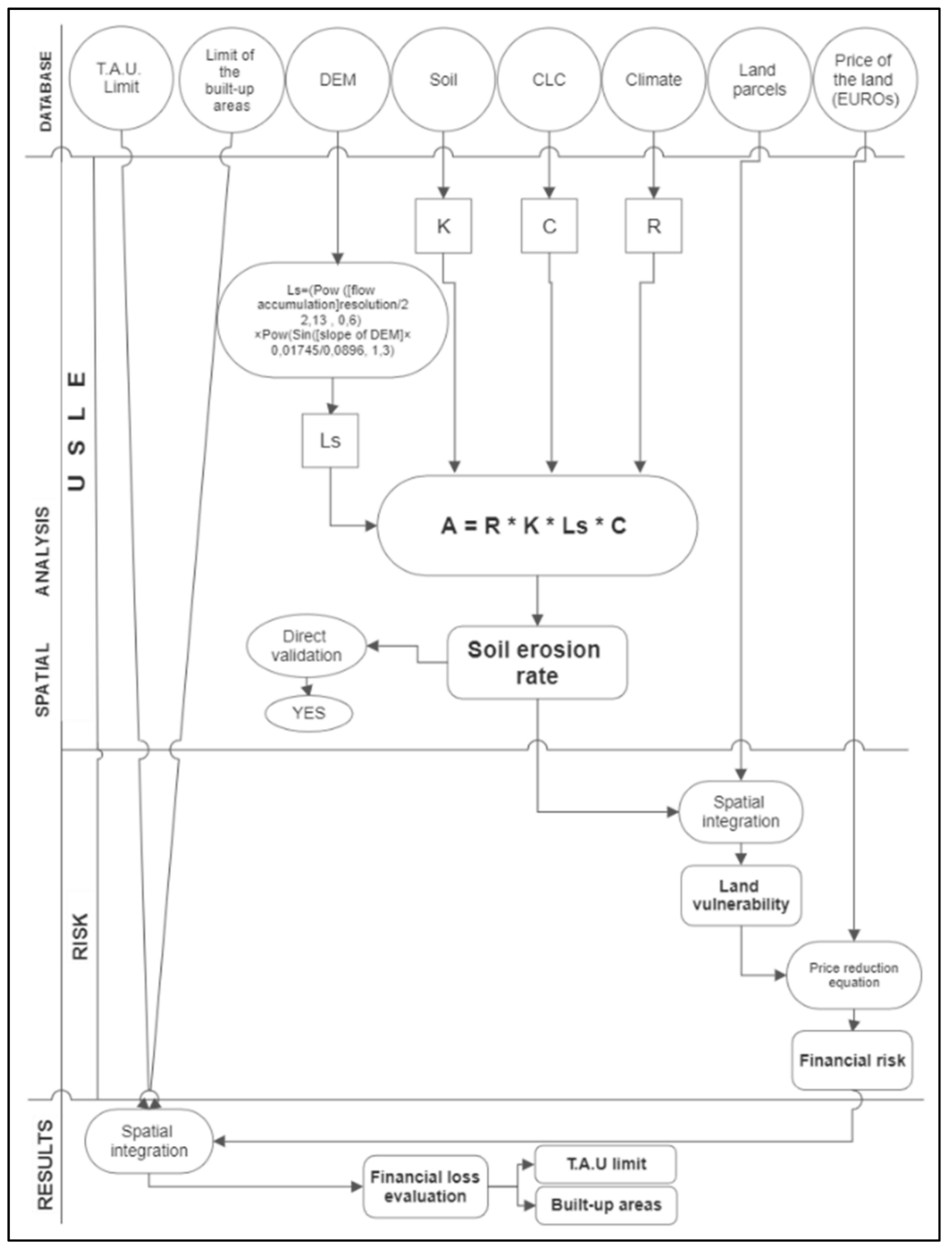

Figure 2. Methodological flow chart.

The spatial analysis model is based on the integrated analysis of five spatialized factors in the form of raster databases: climate aggression index, soil erodibility, topographic index, land use, and the agricultural practices used to combat soil erosion. The analysis performed in the present study is based on the USLE model modified and adapted to the Romanian territory by Motoc M. et al. (1975) [57], using specific coefficients related to land use and soil erodibility. The integration of spatial databases in the GIS model is based on the general equation of soil erosion, as following:

$$
\mathrm{A}=\mathrm{R} \times \mathrm{K} \times \mathrm{Ls} \times \mathrm{C} \times \mathrm{P}
$$

where:

$\mathrm{A}=$ annual soil losses

$\mathrm{R}=$ rainfall erosivity factor

$\mathrm{K}=$ soil erodibility index

Ls = slope length and steepness factor 
$\mathrm{C}=$ cover and management factor

$\mathrm{P}=$ support practice factor

The rainfall erosivity factor $(\mathrm{R})$ reflects the impact of precipitation on soil erosion, as the action of the rainfall is the one that triggers the erosion process and influences soil erosion through the intensity and amount of precipitation. The $\mathrm{R}$ factor quantifies the effect of the impact of raindrops on the soil, and the amount and rate of runoff associated with the rain erosion for individual storm [62].

The soil erodibility factor estimates the soil's response to erosion, depending on the particularities of both the physical and chemical properties of the soil, such as texture, structure, permeability, and content of organic matter [45].

The Ls factor quantifies the impact of topography on soil erosion and is calculated based on slope length and steepness. Topography influences torrential runoff at the surface of the soil, as the erosion capacity of the precipitation is greater with higher slope and length, and thus associate a higher risk. It is calculated using geoinformation software, being derived from the digital elevation model, obtained through the management of the EUDEM digital database, version 1.0, with a spatial resolution of $25 \mathrm{~m}$, which best highlights the morphometric changes in the study area and provides the standard working resolution of the implemented models. The spatial analysis formula used for the spatial identification of the Ls factor was developed by Mitasova et al (1996) [63] and was implemented by the form:

Ls $=($ Pow $([$ flow accumulation $] 25 / 22.13,0.6) \times \operatorname{Pow}(\operatorname{Sin}([$ slope $] \times 0.01745 / 0.0896,1.3)$

The $C$ factor reflects how agricultural practices and soil management influence the rate of soil erosion and indicates the likely evolution of soil losses over time under different land use conditions and with different types of crops [48]. The presence of the vegetal cover at the soil surface has the role of protecting it from the erosive action of the precipitations [1], but different degrees of soil erosion can be identified, depending on the specificities of the plants and agricultural crops. It is calculated through GIS, by assigning a coefficient to each category of land use, according to the model developed by Moțoc M. et al. (1975).

The P factor describes the impact of management practices for soil conservation, through which the rate of soil erosion can be reduced, by changing the runoff pattern, slope or runoff direction [48]. This factor was not considered in this study, as there are no management practices in the study area. Similar approach was made in studies at European scale due to the difficult to estimate this factor for large areas [64] and in detailed studies when these measures did not exist $[65,66]$.

The risk identification is performed on the basis of a complex methodology [67], starting with the surfaces of the cultivated plots, the price of the land in the analyzed areas, the vulnerability of the soil to erosion, and their spatial integration for decision making. From a methodological point of view, the spatial transposition of the elements used for risk assessment implies the progressive decrease of the market value of the lands according to their vulnerability to surface soil erosion. The progressive decrease is based on a relationship of direct proportionality between vulnerability and price, so that the higher the vulnerability, the higher the decrease in the market value of the land, implicitly decreasing its production value.

\section{Results and Discussion}

\subsection{USLE Model Results}

The rainfall erosivity factor $(\mathrm{R})$ has a numeric form, its value for the territory of Romania varying between 0.08 , in the western part of the country, and 0.16 , in the area of Southern Carpathians. The delimitation of this indicator was realized by Motoc M. et al. (1975), based on direct observations from meteorological stations; the data obtained were considered valid for the areas of influence established on physical-geographical considerations and on arbitrary geometric criteria. Within the Guruslău Depression, the 
value of the $\mathrm{R}$ factor is 0.12 for the entire territory, so the rainfall has a medium impact on soil erosion.

The values of the soil erodibility factor $(\mathrm{K})$ were assigned to the soil categories from the study area according to the model developed by Motoc M. et al. (1975) [57] and are valid for the pedological and climatic conditions from Romania, based on criteria related to soil texture, permeability and degree of erosion. The development of the spatial database representing the $\mathrm{K}$ factor is based on the soil map of Romania 1:200,000, vectorized and converted to raster format, at a spatial resolution of $25 \mathrm{~m}$, resolution used for all raster databases used for modelling. The values of the $\mathrm{K}$ factor range from 0.7 for fine-textured soils, to 1.1 for coarse-textured soils with a significant degree of erosion (Figure 3).

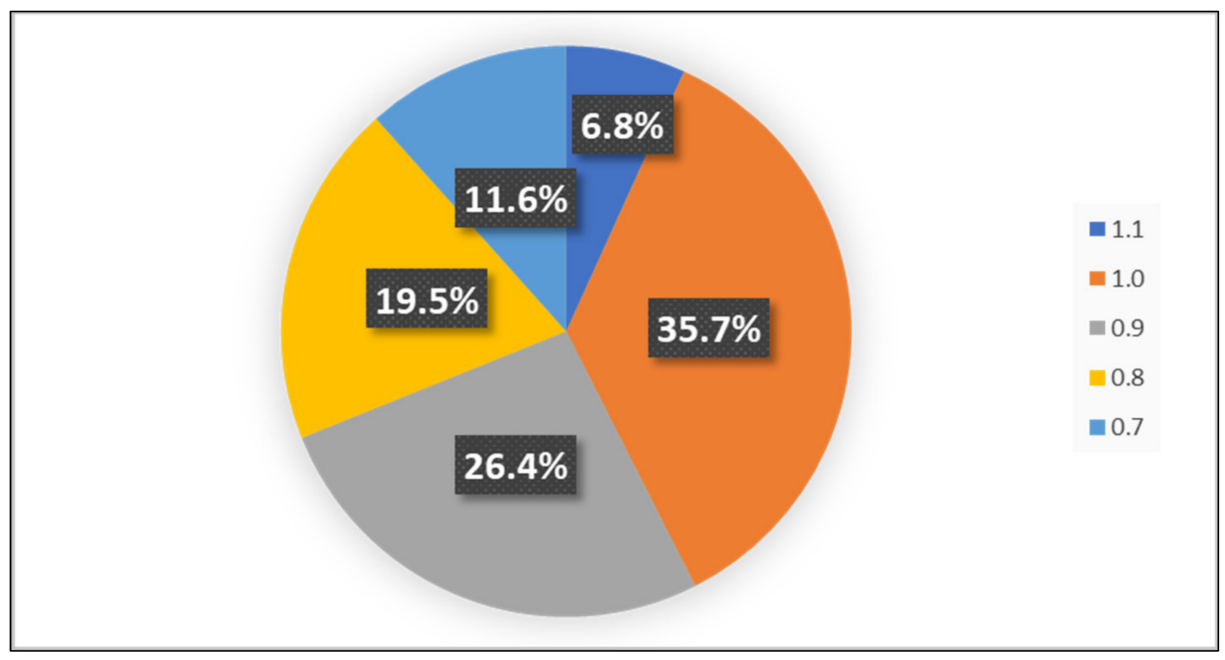

Figure 3. Distribution of the $\mathrm{K}$ factor.

The analysis of the spatial extension of the erodibility factor in the territorial administrative units in the area shows the fact that in the Somes-Odorhei commune is the largest surface with the maximum value of the K factor (40 times higher than in Năpradea commune, where there is the smallest area with the value of 1.1). There are very large areas in the Guruslău Depression with a K factor value of 1, the largest being in Năpradea. Thus this is the commune with the highest risk. The average value of the indicator in the study area is 0.9 , with slightly higher values of 0.91 in Năpradea commune and lower values of 0.89 in Benesat commune. In the city of Jibou, the largest part of the territory has a $\mathrm{K}$ factor value of 1 , followed by the values 0.8 and 0.9 , which reveals a medium risk of soil erosion in this area. On the other hand, the maximum $\mathrm{K}$ factor value occupies the smallest area of the city (of only 100 ha).

The distribution of the $\mathrm{K}$ factor in the study area shows that the value 1 is the most widespread, covering over $35 \%$ of the territory, while the value 1.1 has the lowest weight, of approximately $7 \%$. These two values, summed up, exceed $42 \%$ of the total, so that almost half of the Guruslău Depression has erosion susceptible soils (Figure 4).

The $C$ factor was obtained by modifying the Corine Land Cover (CLC) database, version 2018, by introducing a land use coefficient depending on the type of use and agricultural crop, according to the model developed by Moțoc M. et al. (1975). There were identified 13 categories of land use in the study area, which were assigned coefficients ranging between 0 and 1.2. The lowest value is correlated with the built-up areas, where there is no risk of erosion, while the areas with the highest risk are the unproductive lands that have no vegetal cover. 


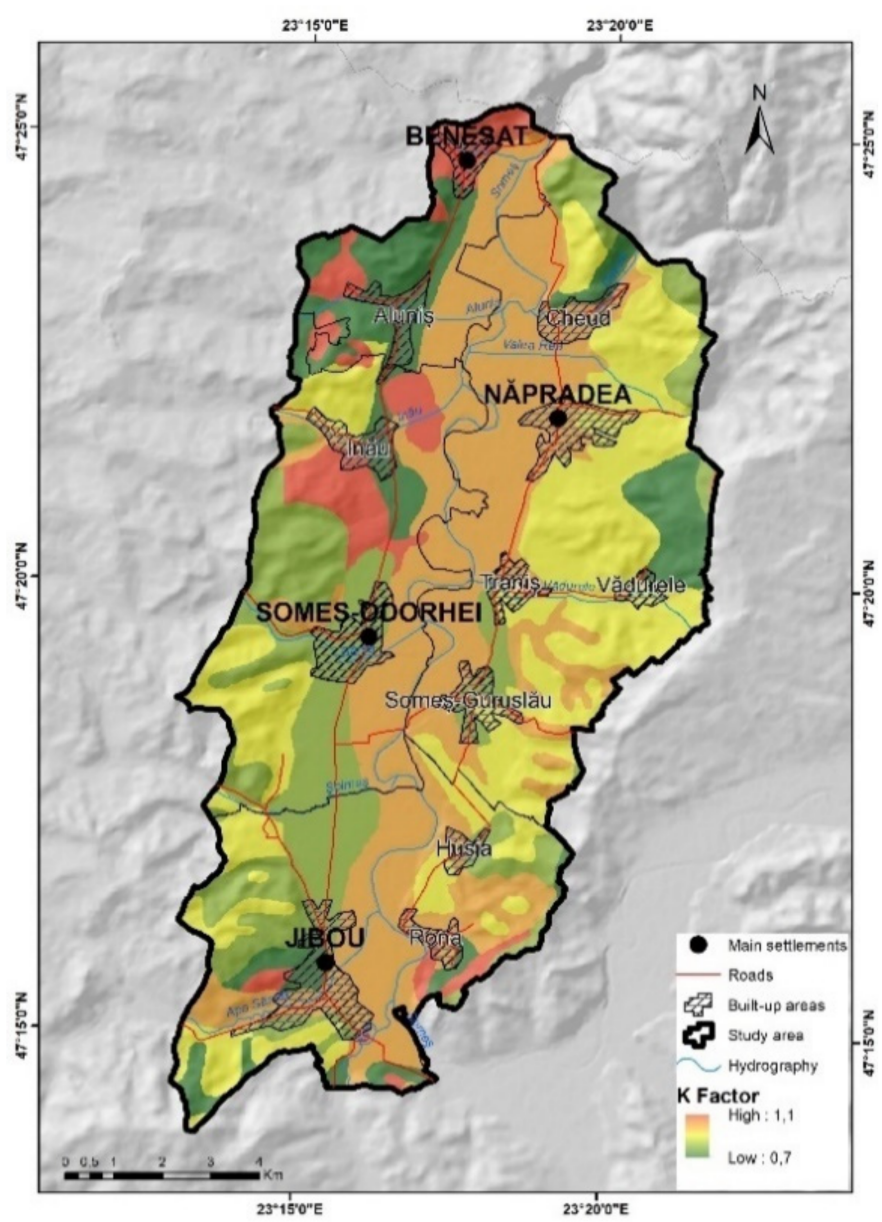

Figure 4. The K factor.

The spatial distribution of the $C$ coefficient indicates that its minimum values, respectively, those between 0 and 0.08 , are the most widespread in each of the four territorialadministrative units, while the values between 0.09 and 0.19 are the least widespread. The largest area with minimum values corresponds to the commune of Năpradea, while the smallest one is in Benesat, so that the distribution is proportional to the areas of the two communes. This is also valid for the spatial distribution of the largest, respectively the smallest area with the maximum value of the $C$ factor, between 0.81 and 1.2, which is located in Năpradea and Benesat. In the city of Jibou and the Someș-Odorhei commune, the largest area, except those with the minimum value, corresponds to the maximum value of the indicator, being followed by the values between 0.5 and 0.8 and those between 0.2 and 0.49 . The average value of the $C$ factor in the study area is 0.26 , the maximum being 0.27 in Năpradea and the minimum is 0.25 in Someș-Odorhei.

The analysis of the distribution of the $C$ factor in the study area shows that its value between 0 and 0.08 occupies the largest area, over $64 \%$, while the smallest percentage, below $1 \%$ corresponds to the values between 0.09 and 0.19 . This means that the land use induces a low risk in most of the territory. However, the values between 0.81 and 1.2, that induce the highest risk, have a significant distribution in the territory, of about $14 \%$, being the second most widespread value in the area, followed by the values between 0.5 and 0.8 , which cover almost $13 \%$. The medium values of the coefficient, between 0.2 and 0.49 , share only about $8 \%$ of the study area (Figure 5 ). 


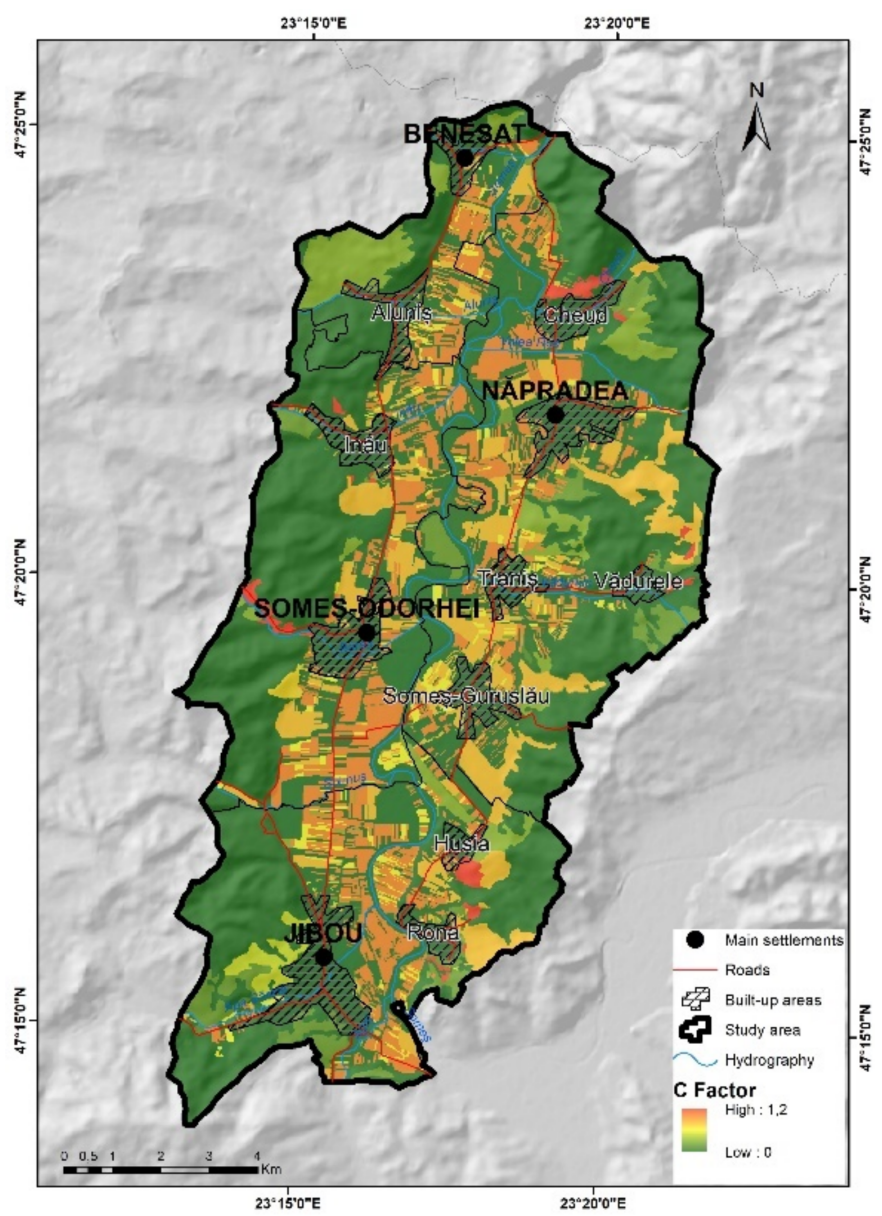

Figure 5. The $C$ factor.

The lowest values of the $\mathrm{K}$ and $\mathrm{C}$ factors are located approximately at the periphery of the study area, so that the risks induced by these indicators are minimal. Meanwhile, the agricultural areas that are located in the meadow and terrace areas of the Somes River, have average values of these coefficients, therefore induce a medium risk in the territory. Within the Benesat commune, there is an extended area with minimum values of both indicators (such that the risk in there is minimal). Overlaps of the minimum values of both indicators are also spread in the southwestern extremity of the study area, in the west of Jibou, and in the east of the Năpradea commune. On the other hand, the overlap of the maximum values of the two coefficients is less significant and is spread on smaller areas, since the maximum values of the $\mathrm{C}$ factor are spread on smaller and less compact areas than those of the $\mathrm{K}$ factor. Such situations can be observed in the northern extremity of Benesat commune and the south-eastern extremity of Jibou city. All in all, there are no large areas with major risk induced by the $\mathrm{C}$ and $\mathrm{K}$ factors (Figure 6). The different distribution of the two indicators at the level of urban areas of localities is noticeable, as the $C$ factor has minimum values in built-up areas, due to the fact that agriculturally cultivated areas are located outside of urban areas, while the distribution of the $\mathrm{K}$ factor does not consider this criterion. However, in the case of Husia and Rona villages, certain peripheral areas have higher values of this indicator. Therefore, the risk induced by the $C$ factor also affects the built-up areas.

The analysis of the percentage distribution of the two factors in the territory shows that while the $\mathrm{K}$ factor induces a high risk in almost half of the territory, the $\mathrm{C}$ factor produces a lower risk, as more than half of the area corresponds to its minimum values. 


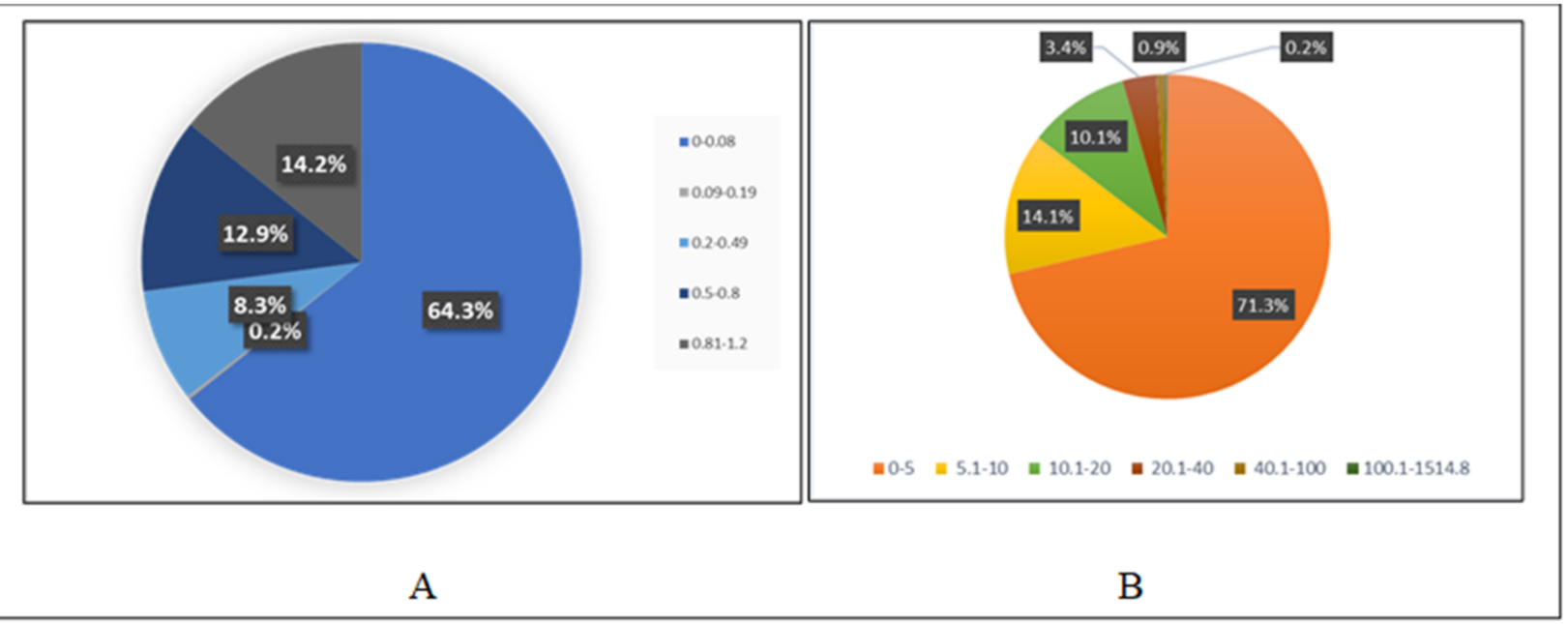

Figure 6. (A) distribution of the $\mathrm{C}$ factor; (B) distribution of the Ls factor.

The values of the Ls factor within the Guruslău Depression range between 0 and 1514.8, their distribution being approximatively concentric, decreasing from the periphery to the central area (Figure 6). The average value is 4.85 , with a maximum of 5.13 in Năpradea and a minimum of 4.43 in Someș-Odorhei. Most of the territory (over 70\%) has an Ls factor in the range of $0-5$, followed by $5.1-10$ and $10.1-20$. The highest values of the Ls factor, in the interval $100.1-1514.8$ and $40.1-100$, occupy approximatively $1 \%$ of the total and their territorial distribution is dispersed in the territory, so that there are few compact areas. Thus, the topographic factor does not induce a significant risk in the Guruslău Depression (but only at the zonal area).

The highest values of the Ls factor are distributed linearly, on the torrential valleys, but also on the terrace bridges and fronts, as in the case of Rona and Husia villages, which belong to the city of Jibou, or in the village of Benesat. The maximum values of the Ls factor are also located in the minor riverbed of the Somes River, but they do not influence the risk in the territory, as they do not have an economic impact. The minimum values of the Ls factor are located at the level of the Somes River meadow and most of the terraces, but also on the interfluves from the periphery of the area. Besides, most of the built-up areas have low values of the indicator, excepting the villages Vădurele, Benesat, Husia and Rona, which are located towards the periphery of the Guruslău Depression (Figure 7).

The assessment of the annual soil erosion rate was realized by implementing the USLE model in the ArcGis software. The values obtained are between 0 and 33.3 ( $\mathrm{t} / \mathrm{ha} / \mathrm{year}$ ), with an average of 0.06 . These values were grouped into 6 classes.

The analysis of the spatial distribution of the soil erosion rate shows that the lowest values, between 0 and 0.2 , are the most widespread, both at the level of the entire study area and of the territorial administrative units. In the case of the first 4 intervals, between 0 and 1.5 , their spatial distribution is inversely proportional to their value, so that the higher the erosion rate, the smaller its surface area. The class with values between 1.51 and 2 has the lowest spatial extension in the territory, being followed by the highest values of the erosion rate, up to 33.3. The Năpradea commune is the most affected by soil erosion, as it has the largest surface with the highest soil erosion rate, approximatively 19 ha, followed by the city of Jibou, Someș-Odorhei and the Benesat commune. In the commune of Năpradea, there is also the largest area with the minimum soil erosion rate, of over 5000 ha, which is also explained by the fact that it is the territorial administrative unit with the largest surface. 


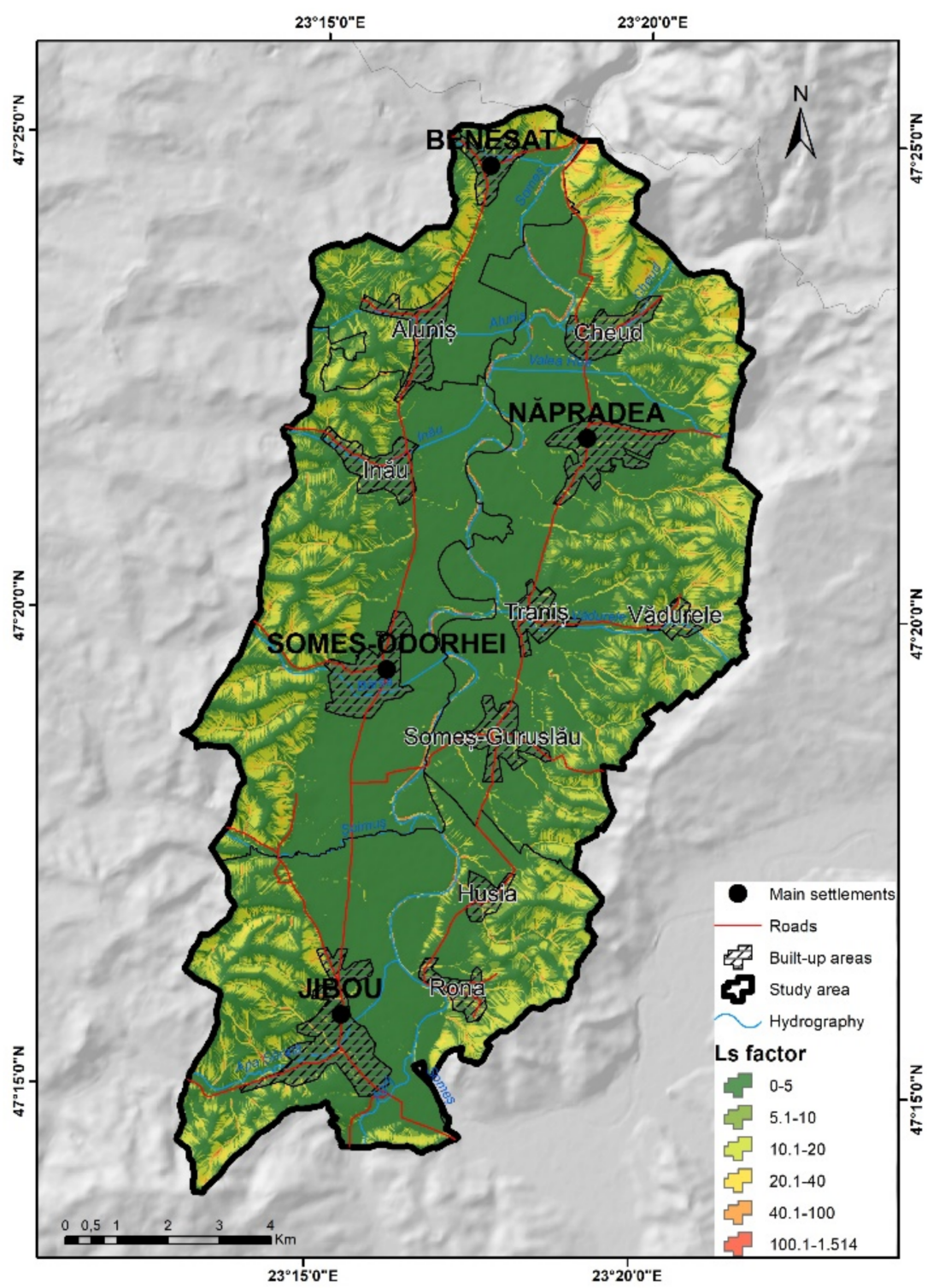

Figure 7. The Ls Factor.

In the Guruslău Depression, approximatively $92 \%$ of the territory has a very low soil erosion rate, between 0 and 0.2 , followed by the intervals of $0.21-0.5$ and $0.51-1$, which account for approximatively $4 \%$ and $2 \%$, respectively (Supplementary Materials). The highest values of over 1.5 occupy the smallest area, about $0.6 \%$ of the total, which means that this process does not significantly affect very large areas (Figure 8).

The highest values of the soil erosion rate in the Guruslău Depression are distributed on isolated areas, such as hotspots. It is important that the built-up areas have small values of this indicator, except for the south-eastern extremity of Husia village, so that the highest rates are in the out-of-town areas, where the agricultural lands are located. This means that the effects of soil erosion have significant impact on agriculture and land productivity (Figure 9).

Hotspots with high values of soil erosion rate can be identified in the east of Jibou, near the villages belonging to it, namely Rona and Husia (Figure 10), but also in the western part of the city. There are also compact areas with high values of the soil erosion rate in the eastern and northern area of Năpradea commune, as well as in its central area. In Benesat commune, the areas affected by soil erosion are located in the northern and western 
extremities, while in the Someș-Odorhei commune the highest values of the soil erosion rate are in the proximity of Bârsa and Inău rivers, in the meadow area of Someș river.

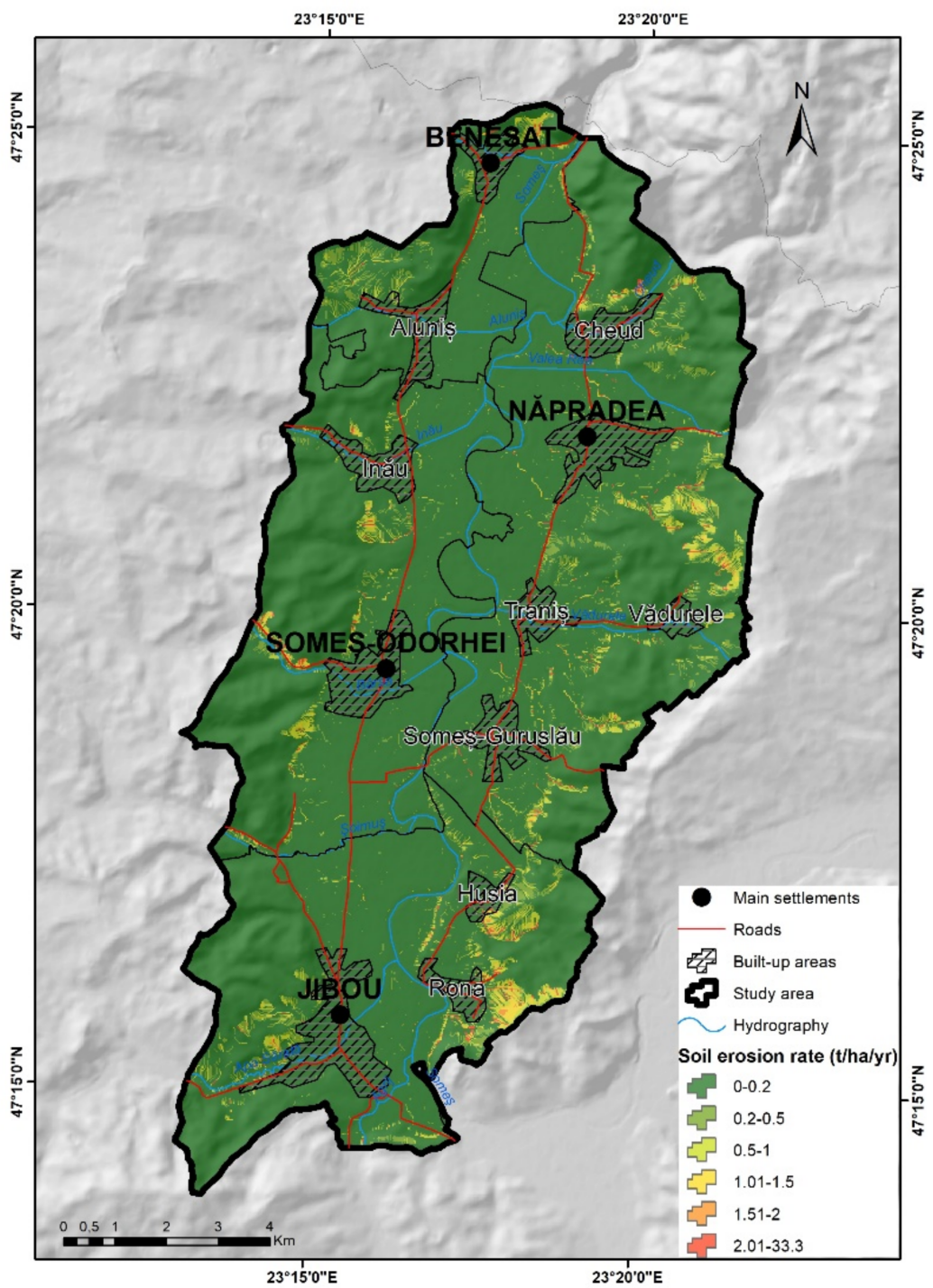

Figure 8. Soil erosion rate.

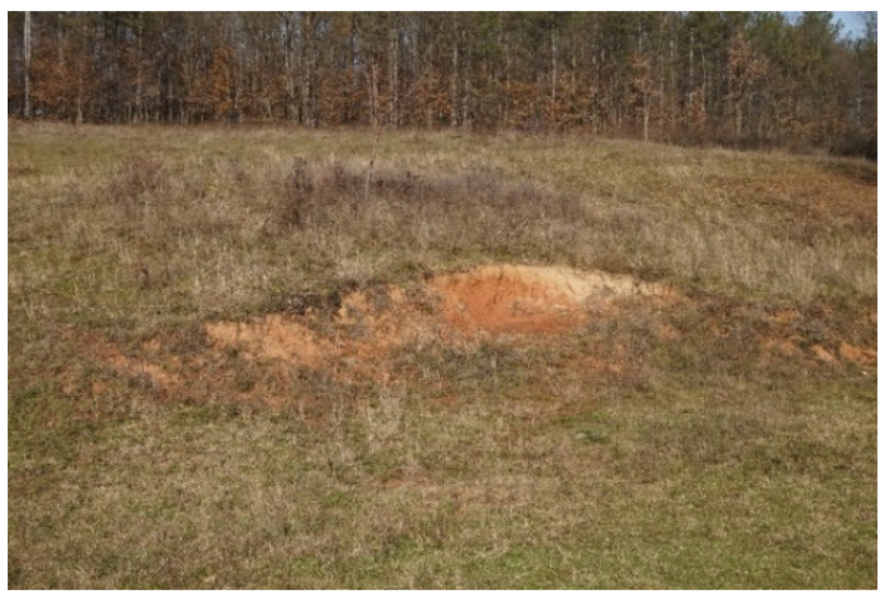

Figure 9. Soil erosion in Vădurele. 


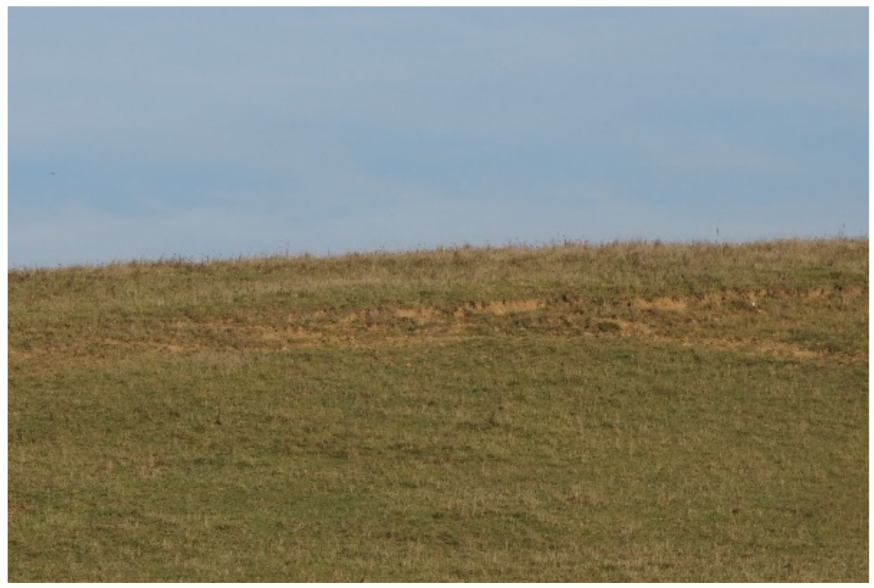

Figure 10. Soil erosion in Husia.

The areas of high erosion identified as a result of the USLE model overlap territorially in a proportion of approximatively $85 \%$ with areas currently affected by soil erosion. Thus, the area from Năpradea commune, from the proximity of Vădurele village and the area from Rona village stand out. In addition, significant areas affected by soil erosion are located in the western part of the built-up area of Someș-Odorhei (Figures 11 and 12).

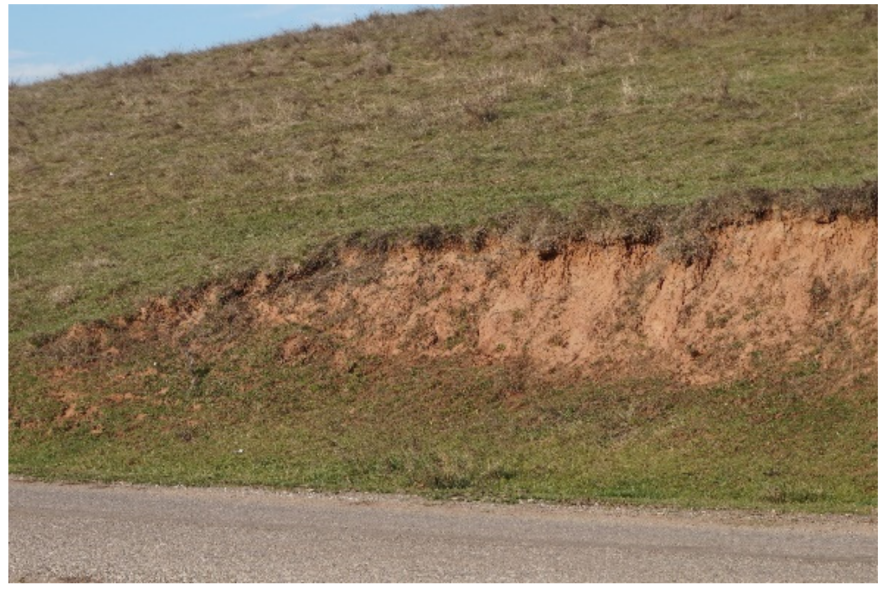

Figure 11. Soil erosion in Someș-Odorhei.

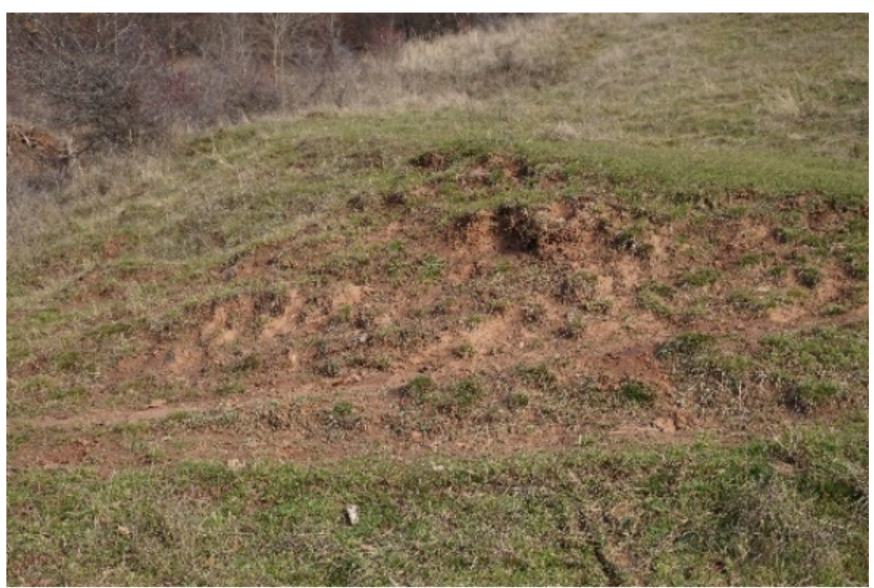

Figure 12. Soil erosion in Someș-Odorhei. 
The large overlap of the results with the reality makes the model being considered valid in terms of results obtained and applicable to the analyzed territory and for performing subsequent spatial analyses to identify risk and make decisions.

\subsection{Risk Evaluation}

The risk assessment in the Guruslău Depression was realized by developing a qualitative model for identifying the financial losses depending on the degree of soil erosion. There were identified the prices of the land parcels in each territorial administrative unit, according to the land use. These prices were processed through GIS and then they were associated to the soil erosion map, in order to determine how much the values of the land decrease. The result was the final risk map.

In a first stage, it was identified the price $/ \mathrm{m}^{2}$ of the land, according to the category of use, based on the available market studies for 2021 [68]. These values were introduced in ArcMap, in the attribute table of the land use. The prices were differentiated for each of the territorial administrative unit component of the study area. The prices in the city of Jibou were higher than those in the rural units, which, in turn, were classified in different categories, so that the communes of Benesat and Somes-Odorhei have the same prices, being included in the " $\mathrm{B}$ " category, while those in Năpradea were lower, as it was included in " $\mathrm{C}$ " category. They vary between 0.04 EURO/sqm, corresponding to the categories "forests" and "non-productive land" from the rural units of the study area, and $0.26 \mathrm{EURO} / \mathrm{sqm}$, corresponding to the vineyards in the city of Jibou.

The total value of each land parcel was calculated by multiplying the area by the price/sqm, using the "Field Calculator" function from ArcMap. The values obtained vary between 0.19 EUROs, corresponding to a very small surface of non-irrigated arable land, and 652.584 EUROs, related to an extended surface of forests. The next step was to reclassify the soil erosion map into five classes, in which one means very high risk and five indicates low risk. The obtained map was used to determine the degree of soil erosion risk for each category of use, by the "Zonal Statistics as Table" function from the Spatial Analyst Tools menu. After this, it was determined the percentage decrease in the value of the land, to calculate the financial losses for each parcel of land. This information was used to generate the final risk map. The amount calculated as a financial loss was then deduced from the initial price, resulting in the value of the land according to the soil erosion risk (Figure 13).

The analysis of the risk calculated as financial loss shows that the impact of soil erosion has effects on five categories of use, namely vineyards, orchards, pastures, complex cultures, and agricultural land, and natural vegetation. The first two categories have losses of 30\%, respectively $20 \%$, while in the case of the last three, the decrease of the value is by $10 \%$. The rest of the land use categories do not have financial losses due to soil erosion.

The highest financial loss in the study area is of 46.801 EUROs, identified at the level of an extended area with orchards, located in the west of Jibou. The loss is significant, since the area has a high financial value, being the category of use located on the second place in terms of price/sqm in the entire study area, after the category of vineyards. The lowest values of the maximum financial losses are in Năpradea commune, being followed by Benesat commune.

The average value of financial losses in the study area is 1.797 EUROs, which is exceeded in Jibou and Benesat, while the other two territorial administrative units have much lower values. The commune of Somes-Odorhei has the lowest losses, despite the fact that is has a very large area, while the Benesat commune, although much smaller, has the highest average losses. 


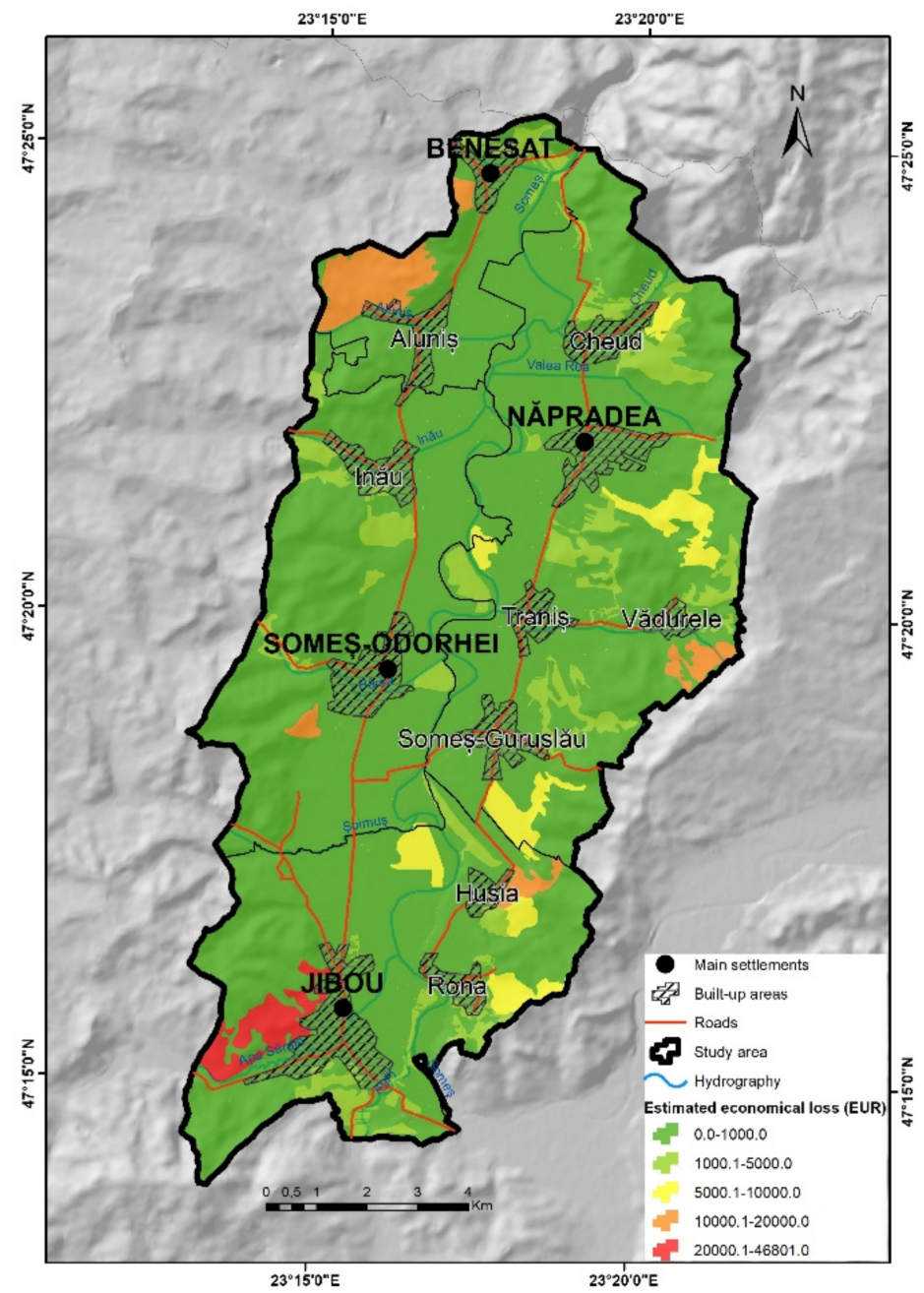

Figure 13. The risk calculated as financial loss.

The analysis of the spatial distribution of the risk shows that the erosion causes financial losses in all territorial administrative units from Guruslău Depression, but the urban center is the most affected, with the highest financial losses and with all categories of risk in it. Apart from the area with the highest risk in the territory, in the city of Jibou there is also a concentration of high-risk areas in the north-eastern part of this unit, in the perimeter of Rona village. Besides, there is an extended area with significant financial losses, between 10.000 and 20.000 EUROs, in the west and north-west of Benesat commune, covering an important part of this unit. High-risk areas are also located in the eastern and southern part of Năpradea commune. In the commune of Someș-Odorhei there are the smallest areas with significant financial losses, noting a single small area in the western part of the unit.

The results obtained based on the implementation of the proposed spatial analysis model highlight the poor management of the lands in terms of their protection against surface soil erosion. Given the fact that the land pretability and land use in the study area highlight large areas cultivated with cereals having as main land use the category of "orchards", it makes most of the production to be used in households and for sale on the market of cities in its area of influence. The assessment of the financial risk on these lands has a very significant utility for the development of integrated land management policies by the local public authorities, having as its main purpose the increase of the production value of the lands affected by soil erosion, while increasing the offer on the market of the products derived from the specific crops of the orchards. The reduction of the risk identified near 
the city of Jibou would maximize the profit obtained as a result of capitalizing on a higher production on the consumer market in the city and neighboring urban centers $[69,70]$. The analysis of the obtained result in the study area can serve as data support for the insurance companies which provide crop insurance to external risk factors (in this case to surface soil erosion).

\section{Conclusions}

The evaluation of the risk induced by soil erosion in the Guruslău Depression was performed by implementing the USLE model in the GIS environment and by developing a qualitative model for assessing the risk quantified in financial losses. The areas with a high risk of soil erosion are not compact and do not occupy very large areas, but they are located in agriculturally cultivated areas, negatively influencing land productivity. Risk assessment in terms of financial losses is useful to identify the effects of soil erosion on agriculture, as this agricultural production supports the development of the area, and land degradation by soil erosion has a direct economic impact on the population (which does not use the land at its maximum productive value). The development of a model for identifying losses to reduce risk makes it easier to assess territorial impact. Risk reduction can be achieved by adapting agricultural practices in areas exposed to erosion and by modifying the crops susceptible to erosion. For example, the areas cultivated with maize in monoculture, which have a high land use management coefficient (1), could be replaced by maize in rotation with cereals, which have a lower coefficient (0.8). Another risk category in which it could intervene is represented by pastures, by limiting intensive grazing in areas with high slopes. Such areas could be identified in the east of Năpradea commune or in the west of Benesat commune, where soil erosion is accelerated by intensive grazing. Another area where it is necessary to take action is the village of Rona, where the risk extends nearly to the built-up area, which is surrounded in the south and east by high-risk areas, caused by intensive grazing combined with high slope. The implementation of the model proposed in the present study on large areas leads to the reduction of costs in terms of crop implementation, with the main purpose on ensuring sales in urban markets and for own consumption, while maximizing profits and reducing financial incentives provided by government agencies to reduce losses due to surface soil erosion. The result of the present model can be used for the evaluation of projects whose main purpose is to establish new species of crops, identifying from the beginning the economic potential of the land and reducing the economic losses, leading to eligible projects for public funding.

Supplementary Materials: The following are available online at https:/ /www.mdpi.com/article/10 .3390/su14020652/s1. Figure S1: Distribution of the soil erosion rate; Table S1: The surface area of the $\mathrm{K}$ factor; Table S2: The surface area of the $\mathrm{C}$ factor; Table S3: The surface area of the soil erosion rate.

Author Contributions: Conceptualization S.B., I.-A.I. and A.C.; methodology A.C. and S.B.; software S.R. and P.S.; validation I.V., A.C. and I.-A.I.; formal analysis A.C.; investigation A.C. and S.B.; resources S.B.; data curation, A.C.; writing-original draft preparation A.C. and I.-A.I.; writingreview and editing A.C. and S.B.; visualization S.R., I.F. and P.S.; supervision I.-A.I. All authors have read and agreed to the published version of the manuscript. All authors have equal contribution in this work.

Funding: This research was funded by the Babeș-Bolyai University through Ph.D studies annual grant.

Institutional Review Board Statement: Not applicable.

Informed Consent Statement: Not applicable.

Data Availability Statement: Not applicable.

Conflicts of Interest: The authors declare no conflict of interest. 


\section{References}

1. Pimentel, D. Soil Erosion: A Food and Environmental Threat. Environ. Dev. Sustain. 2006, 8, 119-137. [CrossRef]

2. $\quad$ Lal, R.; Steward, B.A. Soil Degradation; Springer: New York, NY, USA, 1990.

3. Baskan, O.; Cebel, H.; Akgul, S.; Erpul, G. Conditional simulation of USLE/RUSLE soil erodibility factor by geostatistics in a Mediterranean Catchment, Turkey. Environ. Earth Sci. 2009, 60, 1179-1187. [CrossRef]

4. Angima, S.; Stott, D.; O’Neill, M.; Ong, C.; Weesies, G. Soil erosion prediction using RUSLE for central Kenyan highland conditions. Agric. Ecosyst. Environ. 2003, 97, 295-308. [CrossRef]

5. Hu, Y.; Gao, M. Batunacun Evaluations of water yield and soil erosion in the Shaanxi-Gansu Loess Plateau under different land use and climate change scenarios. Environ. Dev. 2020, 34, 100488. [CrossRef]

6. $\quad$ Pimentel, D.; Kounang, N. Ecology of Soil Erosion in Ecosystems. Ecosystems 1998, 1, 416-426. [CrossRef]

7. Tilman, D.; Downing, J.A. Biodiversity and stability in grasslands. Nature 1994, 367, 363-365. [CrossRef]

8. Oldeman, L.R.; Hakkeling, R.; Sombroek, W.G. World Map of the Status of Human-Induced Soil Degradation: An Explanatory Note; International Soil Reference and Information Centre: Wageningen, The Netherlands, 1990.

9. Oldeman, L.R. The global extent of land degradation. In Land Resilience and Sustainable Land Use; Greenland, D.J., Szabolcs, I., Eds.; CABI: Wallingford, UK, 1994.

10. Ebrahimi, M.; Nejadsoleymani, H.; Sadeghi, A.; Daneshvar, M.R.M. Assessment of the soil loss-prone zones using the USLE model in northeastern Iran. Paddy Water Environ. 2021, 19, 71-86. [CrossRef]

11. Lal, R. Soil erosion by wind and water: Problems and prospects. In 687 Soil Erosion Research Methods, 2nd ed.; Routledge: Oxford, UK, 2017; pp. 1-10.

12. Oldeman, L.R. Global Extend of Soil Degradation, ISRIC Bi-Annual Report 1991-1992; ISRIC: Wageningen, The Netherlands, 1992; pp. 19-36.

13. Hussein, M.H. Water erosion assessment and control in Northern Iraq. Soil Tillage Res. 1998, 45, 161-173. [CrossRef]

14. Borrelli, P.; Robinson, D.A.; Panagos, P.; Lugato, E.; Yang, J.E.; Alewell, C.; Wuepper, D.; Montanarella, L.; Ballabio, C. Land use and climate change impacts on global soil erosion by water (2015-2070). Proc. Natl. Acad. Sci. USA 2020, 117, 21994-22001. [CrossRef] [PubMed]

15. Surya, G. Simulating Climate Change Impact on Soil Erosion and Soil Carbon Sequestration; Indian Space Research Organization: Bangalore, India, 2015.

16. Pruski, F.F.; Nearing, M.A. Runoff and soil loss responses to changes in precipitation: A computer simulation study. J. Soil Water Conserv. 2002, 57, 7-16.

17. Vanacker, V.; Govers, G.; Barros, S.; Poesen, J.; Deckers, J. The effect of short-term socio-economic and demographic change on landuse dynamics and its corresponding geomorphic response with relation to water erosion in a tropical mountainous catchment, Ecuador. Landsc. Ecol. 2003, 18, 1-15. [CrossRef]

18. Chakrabortty, R.; Pradhan, B.; Mondal, P.; Pal, S.C. The use of RUSLE and GCMs to predict potential soil erosion associated with climate change in a monsoon-dominated region of eastern India. Arab. J. Geosci. 2020, 13, 1073. [CrossRef]

19. Koirala, P.; Thakuri, S.; Joshi, S.; Chauhan, R. Estimation of Soil Erosion in Nepal Using a RUSLE Modeling and Geospatial Tool. Geosciences 2019, 9, 147. [CrossRef]

20. Uri, N.D. Agriculture and the Environment-The Problem of Soil Erosion. J. Sustain. Agric. 2000, 16, 71-94. [CrossRef]

21. Keesstra, S.; Mol, G.; De Leeuw, J.; Okx, J.; Molenaar, C.; De Cleen, M.; Visser, S. Soil-Related Sustainable Development Goals: Four Concepts to Make Land Degradation Neutrality and Restoration Work. Land 2018, 7, 133. [CrossRef]

22. Navas, A.; Valero-Garcés, B.L.; Machín, J. Research Note:An approach to integrated assessement of reservoir siltation: The Joaquín Costa reservoir as a case study. Hydrol. Earth Syst. Sci. 2004, 8, 1193-1199. [CrossRef]

23. Samaras, A.G.; Koutitas, C.G. The impact of watershed management on coastal morphology: A case study using an integrated approach and numerical modeling. Geomorphology 2014, 211, 52-63. [CrossRef]

24. Nearing, M.A. Potential changes in rainfall erosivity in the US withclimate change during the 21st century. J. Soil Water Conserv. 2001, 56, 229-232.

25. Williams, J.; Nearing, M.; Nicks, A.; Skidmore, E.; Valentin, C.; King, K.; Savabi, R. Using soil erosion models for global change studies. J. Soil Water Conserv. 1996, 51, 381-385.

26. O’Neal, M.R.; Nearing, M.; Vining, R.C.; Southworth, J.; Pfeifer, R.A. Climate change impacts on soil erosion in Midwest United States with changes in crop management. Catena 2005, 61, 165-184. [CrossRef]

27. Lal, R. Climate Change and Soil Degradation Mitigation by Sustainable Management of Soils and Other Natural Resources. Agric. Res. 2012, 1, 199-212. [CrossRef]

28. Nearing, M.A.; Foster, G.R.; Lane, L.J.; Finkner, S.C. A Process-Based Soil Erosion Model for USDA-Water Erosion Prediction Project Technology. Trans. ASAE 1989, 32, 1587-1593. [CrossRef]

29. Flanagan, D.C.; Nearing, M.A. USDA Water Erosion Prediction Project: Hillslope Profile and Watershed Model Documentation; NSERL Report No. 10; USDA-ARS National Soil Erosion Research Laboratory: West Lafayette, IN, USA, 1995; pp. 1-123.

30. Nearing, M.A.; Pruski, F.F.; O'Neal, M.R. Expected climate change impacts on soil erosion rates: A review. J. Soil Water Conserv. 2004, 59, 43-50.

31. Nearing, M.A.; Deer-Ascough, L.; Laflen, J.M. Sensitivity Analysis of the WEPP Hillslope Profile Erosion Model. Trans. ASAE 1990, 33, 0839-0849. [CrossRef] 
32. Intergovernmental Panel on Climate Change (IPCC). Climate Change 1995. Working Group 1. IPPC; Cambridge University Press: Cambridge, CA, USA, 1995.

33. Pimentel, D.; Harvey, C.; Resosudarmo, P.; Sinclair, K.; Kurz, D.; McNair, M.; Crist, S.; Shpritz, L.; Fitton, L.; Saffouri, R.; et al Environmental and Economic Costs of Soil Erosion and Conservation Benefits. Science 1995, 267, 1117-1123. [CrossRef] [PubMed]

34. Risti 'c, R.; Kostadinov, S.; Radi 'c, B.; Trivan, G.; Niki 'c, Z. Torrential Floods in Serbia-Man Made and Natural Hazards. In Proceedings of the 12th Congress INTERPRAEVENT 2012, Grenoble, France, 23-26 April 2012; pp. 771-779.

35. Ashiagbor, G.; Forkuo, E.; Laari, P.; Aabeyir, R. Modeling soil erosion using RUSLE and GIS tools. Int. J. Remote Sens. Geosci 2013, 2,7-17.

36. Telles, T.S.; Guimarães, M.D.F.; Dechen, S.C.F. The costs of soil erosion. Rev. Bras. Ciência Solo 2011, 35, 287-298. [CrossRef]

37. Bertoni, J.; Lombardi Neto, F. Conservação do Solo, 6th ed.; Ícone: São Paulo, Brazil, 2008; p. 355.

38. Marques, J.F. Costs of soil erosion from an area of high agricultural production. Rev. Econ. Sociol. Rural. 1998, 36, $227-244$.

39. Clark, E.H.; Haverkamp, J.A.; Chapman, W. Eroding Soils: The off Farm Impacts; The Conservation Foundation: Washington, DC, USA, 1985; p. 252.

40. Crosson, P. Impacts of erosion on land productivity and water quality in the United States. In Soil Erosion and Conservation; el-Swaify, S.A., Moldenhauer, W.C., Lo, A., Eds.; SoilConservation Society of American: Ankeny, IA, USA, $1985 ;$ pp. $217-236$.

41. Lane, L.J.; Hernandez, M.; Nichols, M. Processes controlling sediment yield from watersheds as functions of spatial scale. Environ. Model. Softw. 1997, 12, 355-369. [CrossRef]

42. Adinarayana, J.; Rao, K.G.; Krishna, N.R.; Venkatachalam, P.; Suri, J.K. A rule-based soil erosion model for Ahilly catchment. Catena 1999, 37, 309-318. [CrossRef]

43. Abu Hammad, A. Watershed erosion risk assessment and management utilizing revised universal soil loss equation-geographic information systems in the Mediterranean environments. Water Environ. J. 2011, 25, 149-162. [CrossRef]

44. Moore, I.D.; Wilson, J.P. Length-slope factors for the Revised Universal Soil Loss Equation: Simplified method of estimation. J. Soil Water Conserv. 1992, 47, 423-428.

45. Wischmeier, W.H.; Smith, D.D. Predicting Rainfall Erosion Losses-A Guide to Conservation Planning; U.S. Department of Agriculture, Agriculture Handbook No. 537; U.S. Department of Agriculture: Washington, DC, USA, 1978.

46. Renard, K.G.; Foster, G.R.; Weesies, G.A.; McCool, D.K.; Yoder, D.C. Predicting Soil Erosion by Water: A Guide to Conservation Planning With the Revised Universal Soil Loss Equation (RUSLE); U.S. Department of Agriculture, Agriculture Handbook No. 703; U.S. Department of Agriculture: Washington, DC, USA, 1997.

47. Manyiwa, T.; Dikinya, O. Using Universal Soil Loss Equation and Soil Erodibility Factor to Assess Soil Erosion in Tshesebe Village, North East Botswana. Afr. J. Agric. Res. 2013, 8, 4170-4178. [CrossRef]

48. Thomas, J.; Joseph, S.; Thrivikramji, K. Assessment of soil erosion in a tropical mountain river basin of the southern Western Ghats, India using RUSLE and GIS. Geosci. Front. 2018, 9, 893-906. [CrossRef]

49. Grimm, M.; Jones, R.J.A.; Rusco, E.; Montanarella, L. Soil Erosion Risk in Italy: A Revised USLE Approach; European Soil Bureau Research Report No.11, EUR 20677 EN, (2002); Office for Official Publications of the European Communities: Luxembourg, 2003; p. 28

50. Gitas, I.Z.; Douros, K.; Minakou, C.; Silleos, G.N.; Karydas, C.G. Multi-temporal soil erosion risk assessment in N. Chalkidiki using a modified USLE raster model. EARSeL eProceedings 2009, 8, 40-52.

51. Olsen, P.; Kristensen, P.R. Using a GIS system in mapping risks of nitrate leaching and erosion on the basis of SOIL/SOIL-N and USLE simulations. Nutr. Cycl. Agroecosyst. 1998, 50, 307-311. [CrossRef]

52. van der Knijff, J.M.; Jones, R.J.; Montanarella, L.A. Soil Erosion Risk Assessment in Europe, Technical Report; Joint Research Centre European Soil Bureau: Brussels, Belgium, 2000.

53. Blinkov, I.; Kostadinov, S. Applicability of Various Erosion Risk Assessment Methods for Engineering Purposes. Balwois 2010, 2010, 25-29.

54. Nearing, M.; Jetten, V.; Baffaut, C.; Cerdan, O.; Couturier, A.; Hernandez, M.; Le Bissonnais, Y.; Nichols, M.; Nunes, J.P.; Renschler, C.S.; et al. Modeling response of soil erosion and runoff to changes in precipitation and cover. Catena 2005, 61, 131-154. [CrossRef]

55. Bartok, B.; Telcian, A.-S.; Săcărea, C.; Horvath, C.; Croitoru, A.-E.; Stoian, V. Regional Climate Models Validation for Agroclimatology in Romania. Atmosphere 2021, 12, 978. [CrossRef]

56. Harpa, G.; Croitoru, A.; Djurdjevic, V.; Horvath, C.; Djurjevic, V. Future changes in five extreme precipitation indices in the lowlands of Romania. Int. J. Clim. 2019, 39, 5720-5740. [CrossRef]

57. Moţoc, M.; Munteanu, S.; Băloiu, V.; Stănescu, P.; Mihai, G. Eroziunea solului şi metode de combatere; Editura Ceres: Bucureşti, Romania, 1975; p. 301.

58. Bilașco, Ș.; Roșca, S.; Vescan, I.; Fodorean, I.; Dohotar, V.; Sestras, P. A GIS-Based Spatial Analysis Model Approach for Identification of Optimal Hydrotechnical Solutions for Gully Erosion Stabilization. Case Study. Appl. Sci. 2021, $11,4847$. [CrossRef]

59. Sestras, P.; Bilașco, Ș.; Roșca, S.; Dudic, B.; Hysa, A.; Spalević, V. Geodetic and UAV Monitoring in the Sustainable Management of Shallow Landslides and Erosion of a Susceptible Urban Environment. Remote Sens. 2021, 13, 385. [CrossRef]

60. Matei, I.; Pacurar, I.; Roșca, S.; Bilașco, Ș.; Sestras, P.; Rusu, T.; Jude, E.T.; Tăut, F.D. Land Use Favourability Assessment Based on Soil Characteristics and Anthropic Pollution. Case Study Somesul Mic Valley Corridor, Romania. Agronomy 2020, $10,1245$. [CrossRef] 
61. Avram, S.; Ontel, I.; Gheorghe, C.; Rodino, S.; Roșca, S. Applying a Complex Integrated Method for Mapping and Assessment of the Degraded Ecosystem Hotspots from Romania. Int. J. Environ. Res. Public Health 2021, 18, 11416. [CrossRef]

62. Ganasri, B.P.; Ramesh, H. Assessment of soil erosion by RUSLE model using remote sensing and GIS-A case study of Nethravathi Basin. Geosci. Front. 2016, 7, 953-961. [CrossRef]

63. Mitasova, H.; Hofierka, J.; Zlocha, M.; Iverson, L.R. Modelling topographic potential for erosion and deposition using GIS. Int. J. Geogr. Inf. Syst. 1996, 10, 629-641. [CrossRef]

64. Panagos, P.; Borrelli, P.; Meusburger, K.; van der Zanden, E.H.; Poesen, J.; Alewell, C. Modelling the effect of support practices (P-factor) on the reduction of soil erosion by water at European scale. Environ. Sci. Policy 2015, 51, 23-34. [CrossRef]

65. Bilașco, S.; Horvath, C.; Cocean, P.; Sorocovschi, V.; Oncu, M. Implementation of the usle model using gis techniques. Case study the Someşean plateau. Carpathian J. Earth Environ. Sci. 2009, 4, 123-132.

66. Roșca, S.; Bilașco, S.; Fodorean, I.; Vescan, I.; Petrea, D.; Pacurar, I.; Rusu, R. Pedological Risks in Romania. Preliminary Analysis. Riscuri si Catastrofe 2020, 27, 33-45. [CrossRef]

67. Bilașco, S.; Roșca, S.; Fodorean, I.; Vescan, I.; Filip, S.; Petrea, D. Quantitative evaluation of the risk induced by dominant geomorphological processes on different land uses, based on GIS spatial analysis models. Front. Earth Sci. 2018, 12, 311-324.

68. CONCRET DESIGN PLUS SRL. Market Study on Average Values Recorded on the Real Estate Market in 2020, Valid for 2021, Elaborated by SC. Available online: http:/ / www.unnpr.ro/files/expertize2021/CNPCluj/salaj_2021.pdf (accessed on 19 April 2021).

69. Bilașco, Ș.; Roșca, S.; Păcurar, I.; Moldovan, N.; Boț, A.; Negrușier, C.; Sestras, P.; Bondrea, M.; Naș, S. Identification of Land Suitability for Agricultural Use by Applying Morphometric and Risk Parameters Based on GIS Spatial Analysis. Not. Bot. Horti Agrobot. Cluj-Napoca 2016, 44, 302-312. [CrossRef]

70. Bilașco, S.; Roșca, S.; Păcurar, I.; Moldovan, N.; Vescan, I.; Fodorean, I.; Petrea, D. Roads accesibility to agricultural crops using gis technology. Methodol. Aproach Geogr. Tech. 2018, 13, 12-30. [CrossRef] 